\title{
Land Use Scenarios and Their Effect on Potential Crop Production: The Case of Gambella Region, Ethiopia
}

\author{
Azeb W. Degife *, Florian Zabel and Wolfram Mauser \\ Department of Geography, Ludwig-Maximilians-Universität München, 80333 Munich, Germany; \\ f.zabel@lmu.de (F.Z.); w.mauser@lmu.de (W.M.) \\ * Correspondence: a.degife@iggf.geo.uni-muenchen.de; Tel.: +49-89-2180-6695
}

Received: 19 April 2019; Accepted: 5 May 2019; Published: 10 May 2019

\begin{abstract}
Agricultural intensification and cropland expansion are the key policies to increase food production in Ethiopia. Gambella is one of the regions in Ethiopia which is highly suitable for agriculture; however, the local people still face food shortages. We therefore investigated the potential for intensification and cropland expansion. In this study, we developed land use scenarios of agricultural intensification and expansion and analysed their effect on potential crop production in the region and estimated the population that could be nourished as a result. We distinguished between different degrees of intensification, ranging from low input rainfed to high input irrigated agriculture and different degrees of expansion, considering the best $30 \%$ or $50 \%$ of land to be utilized for expansion. While the results reveal that irrigation had almost no effect on potential yields, they also show that the potential calorie production in all scenarios far exceeds the current and possible future caloric requirements of Gambella's population. For example, for the top 50\% expansion scenario, calorie production increased by $+428 \%$ for the low input and by $+1092 \%$ for the high input scenarios. Thus, Gambella could nourish up to 21 million people and serve as a bread basket for the entire country, which could improve national food security.
\end{abstract}

Keywords: cropland expansion; Gambella region; intensification; land use scenarios

\section{Introduction}

According to World Population Review, the total population of Ethiopia in 2018 was about 108 million. With an annual growth rate of $2.46 \%$ [1,2], this number is expected to grow to 174 million by 2050 [2]. Population growth is outpacing agricultural production in Ethiopia [3] and domestic food production has failed to meet the food requirements of the country [4]. The annual food deficit increased from about 0.75 million tons in 1979/80 to 1.4 million tons in 2000 [5]. A series of production failures has resulted in chronic food insecurity since the 1980s and adequate food production has been a serious problem in the country for decades $[4,6]$. According to the UN, Ethiopia has been the largest recipient of food aid among Sub-Saharan African countries [6]. FAO's 2010 report indicated that 5.2 million people in Ethiopia face an uncertain food security situation [7].

Smallholders account for $96 \%$ of the total area cultivated in Ethiopia $[8,9]$. They generate the major share of the total production of the main crops. Teff, wheat, maize, sorghum and barley are the five major cereal crops in Ethiopia, accounting for about three-quarters of the total area cultivated and 29 percent of agricultural Gross Domestic Product (GDP) in 2005/06 (14 percent of total GDP) [9]. However, the Ethiopian population is still undernourished; underscoring the importance of increasing domestic food productivity [10]. One of the greatest challenges for Ethiopia therefore is to meet society's growing food needs whilst reducing the environmental impact of agriculture. The government of Ethiopia has established several programs to address the issue, yet recurring droughts and the population's heavy dependence on rain-fed agriculture, which is plagued by low productivity levels, 
present ongoing challenges for food production [11]. Among the several options that have been discussed to meet future food demand globally [12], there is agreement that increased production is the answer, which can be achieved by (1) intensification and (2) agricultural land expansion [13-16]. A combination of two options will most likely be chosen to meet the challenge: increasing yields through agricultural intensification on existing cropland and increasing production through cropland expansion. Both options have an impact on the environment and society and should be balanced out carefully to identify the best solution. Over the past four decades, increase in crop production in most parts of Ethiopia has occurred predominantly through cropland expansion [17]. However, of late yield increase and intensification rather than area expansion has been the major source of growth in agricultural output in the country [14].

In this paper, we focus on intensification and potential cropland expansion for future agricultural crop production in Gambella National Regional State, which is one of the regional governments forming the Federal Democratic Republic of Ethiopia. The region is endowed with highly diversified natural resources, in particular the large expanse of arable land, rainfall and ground water resources, which render the region best suited for cropland expansion and agricultural development [18]. Despite this "abundance", livelihoods and subsistence farming in the region are still deeply marked by a strong vulnerability to food shortage and large yield gaps [19]. Land fragmentation, farmer's traditions and beliefs, pests, post-harvest management and losses, institutional practices/norms and policy, farmers' resistance to new technology, weak linkages among public, private and non-governmental extension staffs, lack of crop management with respect to planting time and weed control and low usage of organic or mineral fertilizers are the main causes of low productivity and high yield gaps in the region [10,20-24]. We quantify crop yield gaps in the Gambella region and address the related challenges in the interest of increased and sustainable crop production in the region [22]. Although reference/actual yields are documented, there is a lack of insightful statistics and estimates on current yield gaps of the main crops. This information is a prerequisite for developing the region through sustainable intensification and/or expansion of agriculture. We therefore hypothesize that the potential in the Gambella region is huge to increase crop productivity and to improve efficiency of use of the natural resources (water, soil and climate) to meet the growing demand for food in the region and in Ethiopia.

The purpose of this paper is to estimate the magnitude and extent of intensification potential of the key Gambella cereal crops (maize and sorghum) and to identify potential cropland expansion areas in the region. The specific objectives of this paper are: (1) to estimate crop yield gaps and potential production by comparing simulations of potential crop yield and the average reference data/actual achieved crop yields from 1997-2017. Closing yield gaps aims not only at increasing crop yield and production but also at improving the efficiency of land, water and labour use, at reducing production costs and at increasing sustainability through, for example, reduced erosion and increased water use efficiency; (2) to assess potential areas (hot spots) for productivity gains and to identify what percentage of land is needed to accommodate cropland expansion in a manner consistent with sustainable food production and conservation of nature in the future (excluding Gambella National Park, artificial areas, water bodies, wetland and forest land).

Our motivation in this regional study is to give specific insight for scientists, policymakers, local farmers and various stakeholders in the agriculture sectors to overview the potential crop production of the region in a spatially explicit way in high detail, to identify regions where a realization of potentials should be prioritized in the context of region-specific socio-economic conditions through targeted development and to quantify the prospective/capacity of the potential food production of the country and the region.

\section{Materials and Methods}

Intensification potential related with closing yield gaps and agricultural expansion that are based on country or state level empirical data usually neglect spatial heterogeneous distribution of biophysical constraints for crop growth, which are determined by, for example, soil, climate and 
topography. Additionally, empirical quantifications of potential yields often use maximum farmer yields that usually underestimate yield potentials, especially in regions with high yield gaps, such as the Gambella region [25-27]. Thus, combined potentials of intensification and expansion should rely on spatially distributed crop growth models (e.g., gridded). These can be used to simulate potential crop growth for a range of scenarios for all locations in the considered region (even the ones which are not currently under agricultural use) [28]. The scenarios should cover a realistic spectrum of varying management practices like nutrition levels, pest mitigation measures and irrigation intensities, as well as different expansion strategies with respect to where to expand and how much. The resulting spatial simulation results for the different scenarios are compared and the potential as well as the related consequences are documented for each scenario. This paper develops a general framework of intensification/expansion scenarios, which can be used for a broad range of geographical regions in the tropics, for which intensification and expansion of agriculture have to be balanced in order to strengthen food security. The framework is applied to the Gambella region in Ethiopia as a case study to demonstrate its viability.

The framework is shown in Figure 1. Expansion considers only those areas which are (1) feasible with respect to, for example, not being protected areas or biodiversity hot spots and (2) non-agricultural areas to begin with, which show the highest yield potential. Two alternative expansion scenarios are assumed in the study: (1) expansion takes place in the highest yielding 30\% (TOP 30) and (2) 50\% (TOP $50)$ of the feasible rangeland in the area. They assume that expansion takes place in the highest yielding $30 \%$ and $50 \%$ of the feasible rangeland in the area. As illustrated in Figure 1, parallel to these two expansion scenarios we develop three intensification scenarios, which reflect different intensification options ranging from low input rainfed agriculture through high input rainfed agriculture to high input irrigated agriculture. The combination of the assumptions in expansion and intensification leads to 6 scenarios: Low Input Rain-fed (LIR 30 and LIR 50), High Input Rain-fed (HIR 30 and HIR 50) and High Input Irrigated (HII 30 and HII 50) (Figure 1). For all 6 scenarios, we estimate potential yields (t/ha) and production ( $\mathrm{t} / \mathrm{season}$ ), calorie production (reference/actual and potential) and the number of people that can be nourished from the calorie production in the region, based on global average calorie intake.

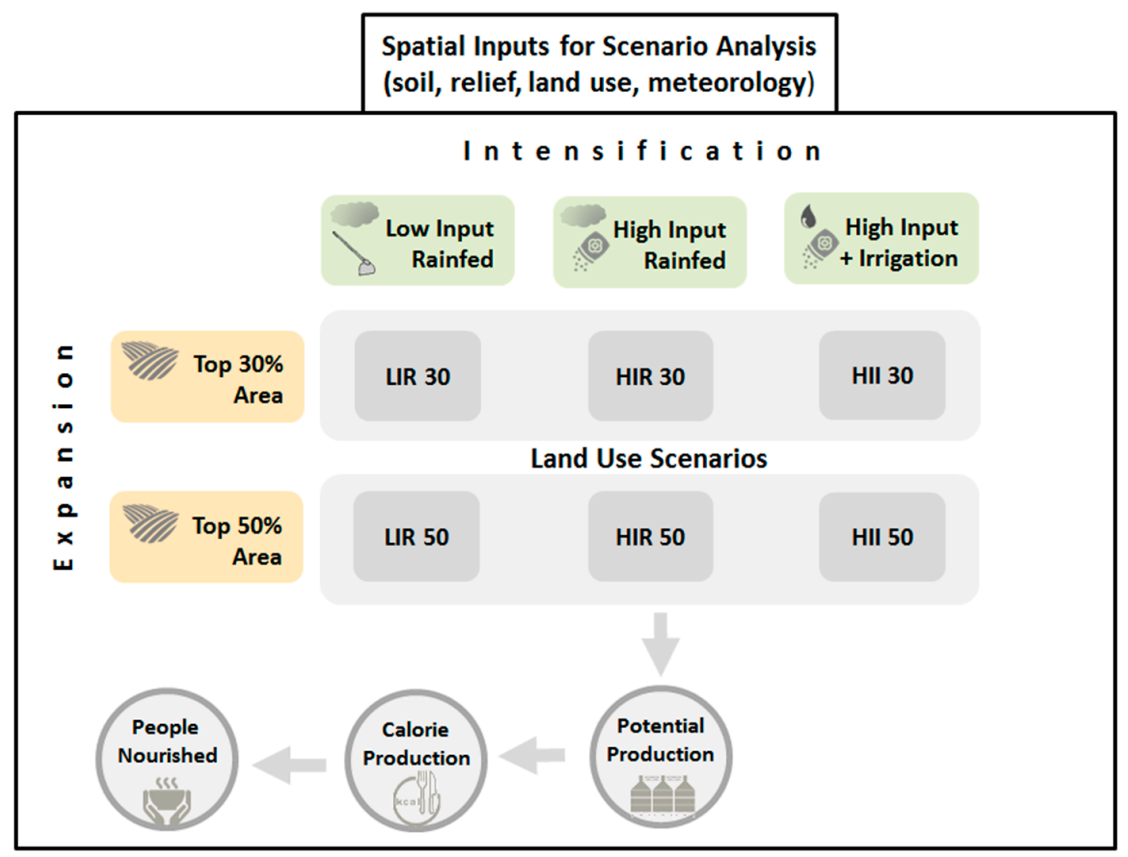

Figure 1. Conceptual framework: Spatial land use scenarios based on assumptions for expansion (brown boxes) and intensification (green boxes). Derived outputs are potential crop- and calorie production and number of people nourished. The scenarios are simulated and analysed spatially, based on spatial information on soil, relief and meteorological drivers. 


\subsection{Study Area}

Gambella National Regional State has been chosen as a regional example to demonstrate the feasibility of the framework. It is situated in the south-western part of Ethiopia, with a total land area of $25,521 \mathrm{~km}^{2}$. It shares a long border with South Sudan and two other Ethiopian regions: Oromia to the north and east and the Southern Nations, Nationalities and Peoples' Regional State (SNNPRS) to the south (as shown in Figure 2). Altitude in the region progressively declines from the east to the west, with parts of the region ranging from 1000 to $2200 \mathrm{~m}$ above mean sea level in the east, to $500-900 \mathrm{~m}$ in the centre and 300-500 $\mathrm{m}$ in the west [29]. Around $90 \%$ of the region is dominated by lowland area [30]. Temperature and rainfall of the region are conducive for agricultural activities. As shown in Figure 3, the annual rainfall ranges between 800 and $1200 \mathrm{~mm}$ and $85 \%$ of rainfall occurs between May and October [31]. The mean annual temperature of the region varies from 17.3 to 28.3 degrees Celsius $\left({ }^{\circ} \mathrm{C}\right)[32]$.

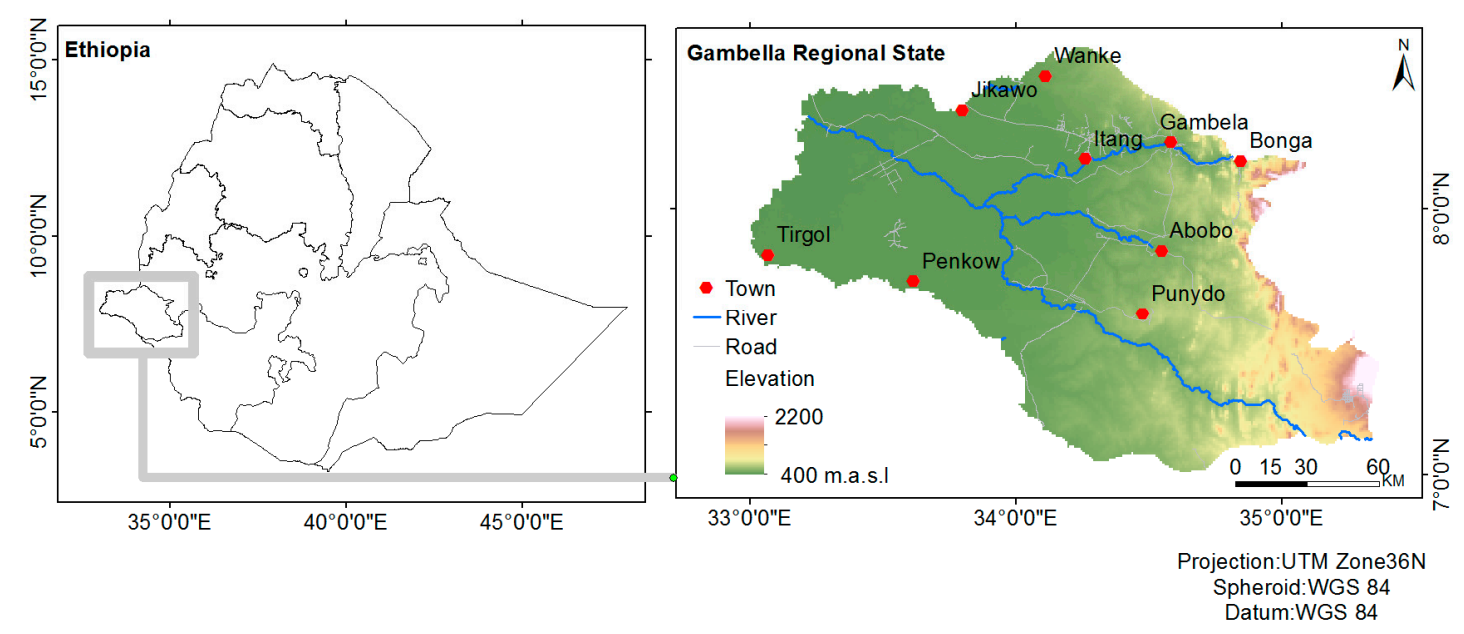

Figure 2. Gambella Locational Map: Federal Democratic Republic of Ethiopia (left) and Gambella Regional State (right).

Gambella National Regional State is one of the Ethiopian regions rich in water resources. The major rivers are the Baro, Akobo, Alwero and Gillo. All of these rivers have major tributaries and are large enough for the local population to depend on, as far as present and future irrigation needs are concerned [33]. Gambella regional state reports indicate the development of first irrigation schemes with total irrigated area of 1315 hectares (ha), out of which 415 ha are from small-scale and 900 ha are from medium scale farms [34]. The rivers originate in the Ethiopian highlands (2000-3500 m) situated in the east of the area and fall to the Gambella plain $(450 \mathrm{~m})$ in the west [28]. The annual potential evapotranspiration in the region reaches about $1612 \mathrm{~mm}$, with the maximum value occurring in March $(212 \mathrm{~mm})$ [32]. According to the 2017 Ethiopian population projection, Gambella is sparsely populated, the total population of the region being approximately 436,000 [35].

Land and water are key resources for the livelihood of the people living in the region [33]. The natural resources make the region potentially an ideal area for both commercial and small-scale farming and therefore for intensification and expansion both by commercial and small-scale farmers. The Ethiopian government has identified Gambella region as one of the regions in Ethiopia suitable for agricultural investments [36-38] and has classified most parts of the area in the region as under-exploited (under-utilized) [39], having a potential for agricultural production. Despite its huge natural resources potential and opportunities [19], the region is one of the poorest in the country [40]. Currently, the livelihood of the region is mainly derived from subsistence agriculture. Flood recession agriculture is common, particularly maize and sorghum, being widely practiced by local people along the rivers [41] and these two crops supply over $70 \%$ of average daily caloric intake in the region [42]. 


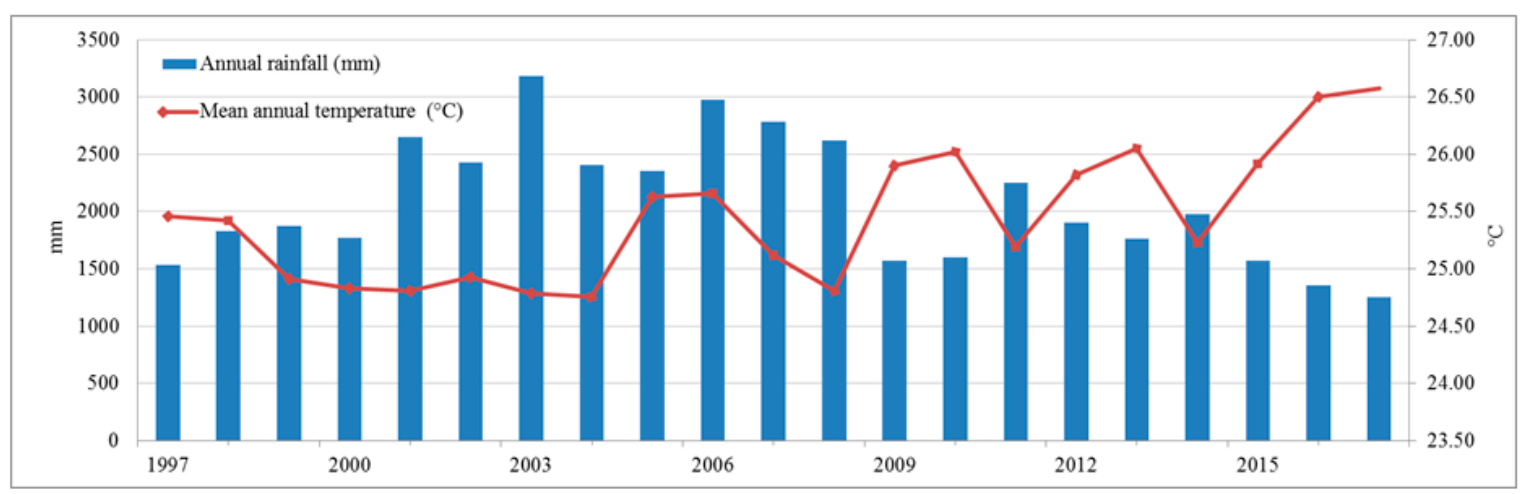

Figure 3. Gambella National Regional State average annual rainfall $(\mathrm{mm})$ and mean annual temperature $\left({ }^{\circ} \mathrm{C}\right)$ (1997-2017) from ERA-interim reanalysis data-set.

\subsection{Reference Data}

The reference yield or actual yield statistics (YA) is defined as the typical average yield of the farmers [43]. We used reference data on yield and harvested area obtained from the Ministry of Agriculture (MOA) and the National Agricultural Statistic Service, Ethiopia's annual Agricultural Sample Survey (AgSS) and Ethiopia's Central Statistics Authority (CSA), which provides critical information on small-scale farmer reference/actual crop yields and management practices for maize and sorghum from 1997 to 2017 at the regional level. Moreover, we used several additional sources of information such as localized agricultural information from the Gambella Regional Bureau of Agriculture.

\subsection{Simulation of Potential Yields}

One of the common crop modelling applications is the estimation of potential productivity under different assumptions of biophysical constraints [44]. We use the model (PROMET) (Processes of Mass and Energy Transfer [27,45]). PROMET is an agro-hydrological land surface process model, which contains a mechanistic, bio-physical, dynamic vegetation component to model crop growth and yield formation [46,47]. PROMET allows spatially distributed, raster-based simulations, which model net primary production, evapotranspiration, water balance and yield at different scales, from field to global, as a function of meteorological drivers as well as soil and terrain information. PROMET determines and considers water availability through soil moisture balance, radiation balance and the physiological regulation mechanisms of plant canopies [47,48]. The dynamic crop growth component uses parameters, which represent the sensitivity of the crops to environmental conditions (e.g., temperature, soil suction, nutrient supply) and which determine phenological development and crops reactions to related stresses. Management practices such as crop cultivar selection, sowing date, harvest date and fertilization levels are considered [45]. PROMET is well parameterized and validated for (but not restricted to) the simulation of the two important Gambella cereal crops, maize and sorghum (see, e.g., Reference [27]). The required parameters for this paper were either derived from the literature [49] or determined through comparison with recorded yields in different parts of the globe. The spatial nature of PROMET also allows localizing the potential of cropland expansion through considering biophysical drivers at the local scale, such as climate, soil quality and topography. Simulation of potential yields outside the actual cropland allows determining where an expansion of cropland would potentially be most feasible under the given natural conditions.

The model takes into account the spatial heterogeneity of the study area with reference to climate, soil and terrain conditions. We simulate the potential agro-ecological yields of the selected crops for all agriculturally suitable and feasible geographical locations in Gambella region. In this paper we have defined yield potentials (YP) as theoretically optimum yields that can be achieved with certain assumptions on crop management. At each location in the region, optimal management creates a yield 
potential depending on the environment. Options can, for example, be assumed as rainfed agriculture or irrigated agriculture, no nutrition, low input nutrition or high input for a particular cultivar $[43,50]$. In our study we assume well adapted standard cultivars of maize and sorghum, optimal sowing and harvest dates and no harvest losses due to pests or diseases, as well as no further losses during transport or storage. For simulating the yield potentials for the 6 scenarios from Figure 1, we use different combinations of the mentioned management options. For each scenario, PROMET is run for the whole actual as well as the potential and feasible cropland in the Gambella region, with a spatial resolution of 30 arc seconds (approx. $940 \times 940 \mathrm{~m}$ at the Equator). It is driven by meteorological inputs of the years 1997-2017, which are statistically downscaled from the 0.5 degree (approx. $50 \mathrm{~km}$ ) ERA-Interim reanalysis data-set [51] to the model resolution. Soil data is derived from the Harmonized World Soil Database (HWSD) and topography from the SRTM (Shuttle Radar Topography Mission) data-set [27].

\subsection{Land Use Scenarios}

\subsubsection{Expansion}

This part is concerned with cropland expansion to improve the potential food production in the region. For this purpose, we developed a "TOP 30\% cropland expansion" and a "TOP 50\% cropland expansion" scenario on land conversion and expansion in the Gambella region. Both rest on an identified potential cropland of 1,436,500 ha (from our pervious land use land cover classification of the region (see, e.g., Reference [39]), we identified potential cropland). We consider Ethiopian land use regulations and legislation and exclude artificial areas, water bodies and protected areas according to the International Union for Conservation of Nature (IUCN) [52]. Accordingly, the Gambella National Park, forest land [53] and wetland vegetated areas [54] and current cropland are excluded from potential expansion areas. We assume in the scenario that agricultural expansion strategically follows a gradient from high to lower yield potentials. It is therefore assumed that expansion starts at the location with the highest potential and consecutively selects locations with the next lower potential. We further assume that not all possible expansion will take place, because investments have to take place and they have to be financed by a return that is diminishing with expansion because of decreasing yield potentials. We therefore define a TOP $30 \%$ and TOP 50\% expansion scenario, where the best 30\% $(375,000$ ha, high investment costs) and 50\% (600,000 ha, lower investment costs) of potential farmland are used for cropland expansion. These expansion areas are identified by ordering the PROMET simulation results of each pixel according to their yield potentials and then selecting the corresponding best $30 \%$ and $50 \%$ pixels.

\subsubsection{Intensification}

Currently, around 280,000 ha of land in the Gambella region is covered by cropland. It consists of both small and large-scale farms. It is therefore unrealistic to assume that intensification can completely close current yield gaps, because of many factors which in practice work against it, such as severe weather and pests. We assume two scenarios for rainfed and irrigation, in which intensification closes the yield gap between the potential and the reference yield statistics by approx. $10 \%$ (LIR) and $40 \%$ (HIR and HII). A closure of yield gaps by $10 \%$ until 2050 corresponds to a continuation of current trends with average yield increases from 1997-2017 and can be considered "business as usual". We linearly regressed 20 years of crop yields to determine the average linear rates of yield improvement over the observed period. Many previous studies [55] have shown that crop yields increase linearly with time and we have used linear regression to project crop yields. We also close the yield gap by approx. $40 \%$ by assuming that the future agricultural outputs will follow a growth pattern which is similar to that of Ethiopia's current overall fast-growing economy. These considerations lead to three assumptions for intensification: low input rain-fed, high input rain-fed and high input irrigation. 
- LIR scenario: we assume that intensification closes the yield gap between the potential and reference yield statistics by approx. $10 \%$ until 2050. However, we assume that there might be constraints to achieving potential production because of traditional ploughs, weak cooperatives and institutions, low technological development, less organized pest management or expensive pesticides, lack of a strong agricultural policy or economic institutions like leasing and no access to credit for the farmers. In general, in the LIR scenario we assume that "business as usual" continues until 2050.

- HIR scenario: we assume that intensification closes the yield gap between the potential and the reference yield statistics by approx. $40 \%$ until 2050. In the high input there is a large potential to increase rain-fed yields of maize and sorghum by increasing agricultural inputs through mechanization and fertilization and by improving infrastructure, education and governance.

- HII: we assume the same agricultural development as in high input rain-fed; however, in this case the water deficits of rainfed agriculture would be compensated through irrigation.

\subsection{Reference Crop Calorie Production and Calorie Intake}

In this paper we consider the 2 major food crops maize and sorghum. These crops account for $97 \%$ of Gambella region's crop production by small scale farmers and $95 \%$ of the region's harvested area [56]. We further assume that the current ratio of cultivated area of 50\% maize and $50 \%$ sorghum will stay constant when closing yield gaps [57]. In order to convert reference/actual and potential production into meaningful information with respect to food security for the residents of Gambella and beyond, production has to be converted from mass into calories. We calculate the current small scale farmland crop calorie production for each crop (Ca) according to Equation (1) using the statistical data on the reference crop yield (Yar: rain-fed) and area harvested $\left(\mathrm{H}_{\mathrm{r}}\right)$ and FAO's nutritive factors for converting crop mass into calories $\left(\mathrm{f}^{\mathrm{i}}\right)$ [58,59] (Table S1). For both crops, calorie production under reference yield and yield gap closure scenarios was assessed based on the respective crop yield values $\left(\mathrm{t} \mathrm{ha}^{-1}\right)$. The number of people that can be fed is assessed based on a global estimate of average daily per capita calorie consumption (2200 kcal/cap/day) [60].

$$
\mathrm{Ca}=\sum\left(\mathrm{Ya}_{\mathrm{r}} \times \mathrm{H}_{\mathrm{r}} \times \mathrm{f}^{\mathrm{i}}\right)
$$

\subsection{Simulations of Potential Crop Calorie Production and Calorie Intake}

PROMET was run for the Gambella region on the actual and all potential and feasible cropland for the six selected scenarios for the period from 1997 to 2017, with a spatial raster grid of 30 arc seconds (approx. $940 \times 940 \mathrm{~m}$ ) resolution, to provide information on potential crop yields [45]. The extended simulation period of 20 years was chosen to be able to average yield potential over a large range of weather situations. We used PROMET data on potential yields for estimating the potential crop calorie production both for the current farmland and potential and feasible cropland. The potential crop yields are provided in $\mathrm{tha}^{-1}$ in harvest weight, assuming common moisture content of harvested fruits, which is 12.75 . The nutritive factor $\left(\mathrm{f}^{\mathrm{i}}\right)$ is used to convert crop mass into crop calories. The crop production based on rain-fed and irrigated agriculture obtained by multiplying for each pixel in the simulation the high input potential yields $\left(\mathrm{YP}_{\mathrm{r}}\right.$ and $\mathrm{YP} \mathrm{P}_{\mathrm{i}}, \mathrm{r}$ : rain-fed, $\mathrm{i}$ : irrigated) and area harvested $\left(\mathrm{H}_{\mathrm{r}}\right.$ and $\mathrm{H}_{\mathrm{i}}$ ) provides the potential crop calorie production for high input levels $(\mathrm{Ch})$ according to Equations (2) and (3). Finally, the crop calorie production values of $50 \%$ maize and $50 \%$ sorghum are added to get the total potential crop calorie production from the two crops and accordingly the number of people that can potentially be fed based on a global estimate of average daily per capita calorie consumption (2200 kcal/cap/day) [60].

$$
\begin{aligned}
& \mathrm{Ch}_{\mathrm{r}}=\sum\left(\mathrm{YP}_{\mathrm{r}} \times \mathrm{H}_{\mathrm{r}} \times \mathrm{f}^{\mathrm{i}}\right), \\
& \mathrm{Ch}_{\mathrm{i}}=\sum\left(\mathrm{YP}_{\mathrm{i}} \times \mathrm{H}_{\mathrm{i}} \times \mathrm{f}^{\mathrm{i}}\right),
\end{aligned}
$$


To analyse the state of self-sufficiency of the population, we take the UN world population prospective report of 2017 [61]. It assumes that the total population of the region will roughly double from 436,000 in 2017 to around 880,000 in 2050.

\section{Results}

\subsection{Land Use Scenarios' Effect on the Potential Yield from 1997-2017}

As shown in Figure 4, potential yields are spatially highly variable due to more or less suitable climate and soil conditions for farming in the region. In general, rainfed potential yields (as shown in Figure $4 \mathrm{~A}, \mathrm{C}$ ) decrease from high values in the north to lower values in the south of Gambella because of poor sandy Alisols in the south. The highest potential rainfed yields are simulated for both crops in the western highlands because of plenty of rainfall and reduced temperature stress. By selecting the current farmland from Figure 4 which closes the reference yield gap of maize and sorghum by $40 \%$, the average potential yields on all possible and feasible cropland becomes $6.1 \mathrm{t} \mathrm{ha}^{-1}$ for maize and $2.7 \mathrm{t} \mathrm{ha}^{-1}$ for sorghum for the HIR intensification assumption and $6.4 \mathrm{tha}^{-1}$ and $2.8 \mathrm{tha}^{-1}$ for maize and sorghum respectively for the HII assumption (Figure 4B,D). The related simulations were also carried out for the LIR assumption by selecting the current farmland from Figure 4, which closes the reference yield gap of maize and sorghum by $10 \%$, for the whole potential and feasible cropland. Here, the average potential yields of maize and sorghum are $1.5 \mathrm{t} \mathrm{ha}^{-1}$ and $0.7 \mathrm{tha}^{-1}$, respectively. The CSA report shows that the average reference yield in Gambella region from 1997-2017 is $2.1 \mathrm{t} \mathrm{ha}^{-1}$ for maize and $1.1 \mathrm{t} \mathrm{ha}^{-1}$ for sorghum.

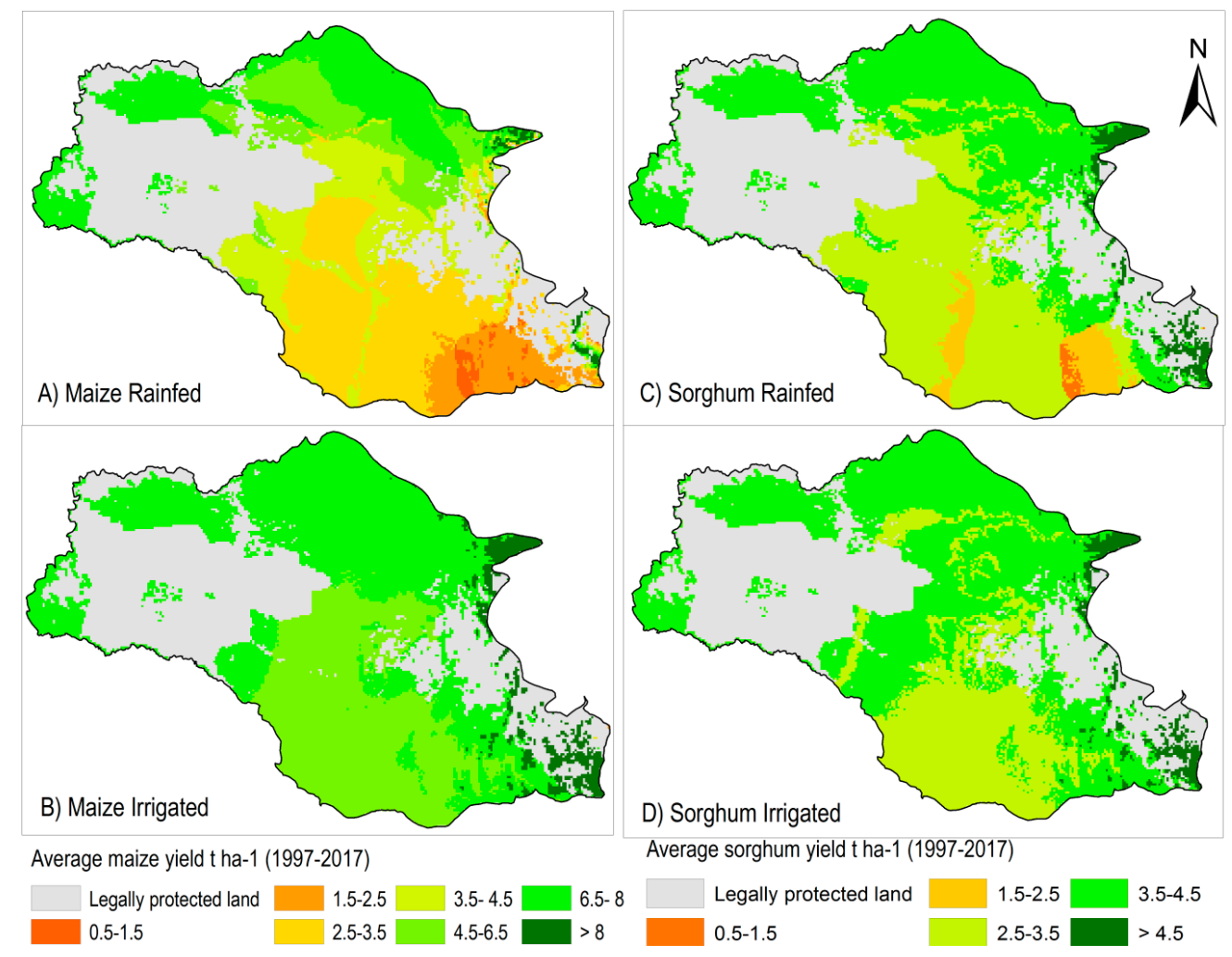

Figure 4. Average maize and sorghum yield on the total potential cropland area in high input-rainfed (HIR) and high input-irrigated (HII) scenarios. Potential yield which is simulated based on PROMET: HIR maize (A) \& sorghum (C) on the potential cropland (including the current cropland) identified as low environmental opportunity cost and legally available lands where it is possible to convert the tract of land to cropland with rain-fed agriculture. HII maize (B) \& sorghum (D) show simulated potential yields assuming perfect irrigation (no water stress). 


\subsection{Effect of Scenarios on the Potential Crop Production (1997-2017)}

By identifying the $30 \%$ and $50 \%$ of all harvested pixels in Figure 4 which show the highest yields, we realize the spatial distribution of the two expansion assumptions TOP 30 and TOP 50. The resulting spatial expansion of cropland in Gambella is shown in Figure 5, together with the actual cropland. Figure 5 shows that expansion is predominantly identified in the north and west of Gambella. PROMET simulates the average potential yield of maize in rain-fed agriculture in the LIR 30 and HIR 30 scenarios to be $2.9 \mathrm{t} \mathrm{ha}^{-1}$ and $7.5 \mathrm{tha}^{-1}$, respectively. In HII 30, irrigation increases the average maize yields from 7.5 to $7.7 \mathrm{tha}^{-1}$. Average sorghum yield in the LIR 30 and HIR 30 scenarios is around 2.0 and $4.0 \mathrm{t}$ $\mathrm{ha}^{-1}$, respectively. At the same time in HII 30 irrigation increases the average yield of sorghum from $4.0 \mathrm{t} \mathrm{ha}^{-1}$ to $4.3 \mathrm{t} \mathrm{ha}^{-1}$. Similarly, in LIR 50 and HIR 50, average maize yield in the region is $2.9 \mathrm{t} \mathrm{ha}^{-1}$ and $7.5 \mathrm{tha}^{-1}$ respectively, whereas in HII 50 average maize yield is around $7.7 \mathrm{tha}^{-1}$. On the other hand, in LIR 50 and HIR 50, average sorghum yield is $2.1 \mathrm{tha}^{-1}$ and $4.1 \mathrm{tha}^{-1}$ respectively, while in HII 50 average sorghum yield is $4.3 \mathrm{t} \mathrm{ha}^{-1}$. The result indicates that the average yield of maize and sorghum in HIR 30 and HIR 50, as also in HII 30 and HII 50, does not show any significant difference.

The result shows that average maize and sorghum reference yield production are $0.4 \mathrm{Mt}$ and 0.3 Mt respectively from 1997-2017. In the LIR 30, maize average yield production is $1.8 \mathrm{Mt}$ and it increases by $350 \%$ compared to the average maize yield reference production. In the HIR 30 and HII 30 average maize production is $4.4 \mathrm{Mt}$ and $4.5 \mathrm{Mt}$ respectively, increasing by $1000 \%$ and $1025 \%$ respectively compared to the average maize yield reference production. The small percentage increase in production from the HIR 30 to the HII 30 scenario confirms the excellent natural suitability and adequacy of rainfall of Gambella region for crop production. In the LIR 50, average maize production is $2.5 \mathrm{Mt}$ and increases by $525 \%$ compared to the average maize yield reference production, while in the HIR 50 and HII 50 the average maize yield production is $6.1 \mathrm{Mt}$ and $6.3 \mathrm{Mt}$, respectively. In the LIR 50 and HIR 50, average maize yield production is about 5 and 15 times respectively of the average maize reference yield production.

The result indicates that in the LIR 30 scenario the average sorghum yield production is $1.2 \mathrm{Mt}$ and this is an increase of $300 \%$ compared to average sorghum reference yield production. In the HIR 30 and HII 30, average sorghum yield production is $2.4 \mathrm{Mt}$ and $2.5 \mathrm{Mt}$ respectively, increasing by $700 \%$ and $733 \%$ respectively compared to today's production/average sorghum reference yield production. Again, the effect of irrigation is marginal for sorghum. Under LIR 50 the average sorghum yield production is $1.7 \mathrm{Mt}$ and increases by about $467 \%$ compared to average sorghum reference yield production. By repeating the same simulations, sorghum average yield production on the potential cropland in the HIR 50 and HII 50 is $3.4 \mathrm{Mt}$ and $3.5 \mathrm{Mt}$ respectively, reflecting an increase of $1033 \%$ and $1067 \%$ respectively compared to the average sorghum reference yield production. This yield production result shows that the total simulation potential production of HIR and HII in the region does not reflect any significant difference, which implies that annual rainfall of the region is enough for production of maize and sorghum. Figure 5 shows that spatial distribution of the total area coverage of the two scenarios (TOP 30 and TOP 50) would be located in the northern parts of the region where there is high yield production per ha. Both cropland expansion scenarios in the region could take place at the expense of tropical grasslands and sparsely vegetated lands of the region (see, e.g., Reference [39]). 


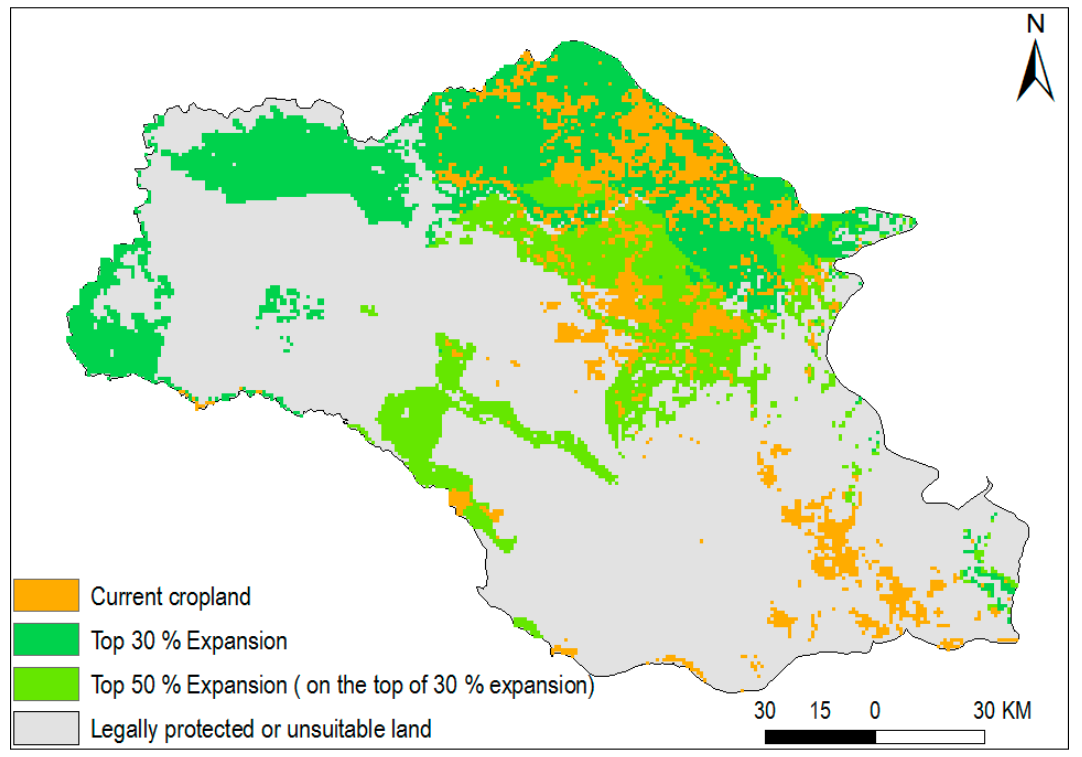

Figure 5. The total area coverage of current cropland, TOP 30 and TOP 50 land use scenarios and legally protected area in the Gambella Region.

\subsection{Scenarios' Effect on the Potential Calorie Crop Production and Calorie Intake}

Section 3.2 documented the huge gap between reference and simulated potential crop production in the region. In order to convert reference and potential production figures into meaningful information with respect to food security for the residents of Gambella, the values have to be converted from mass into caloric production. The result shows that total average reference crop calorie production is around $1.4 \times 10^{12} \mathrm{kcal}_{\text {year }}{ }^{-1}$ from 1997-2017. In LIR 30 the total average crop calorie production is around $5.40 \times 10^{12} \mathrm{kcal}_{\text {year }}{ }^{-1}$, which is an increase of around $286 \%$ compared to average reference crop calorie production. Total average crop calorie production of HIR 30 is about $1.20 \times 10^{13} \mathrm{kcal}_{\text {year }}{ }^{-1}$. The simulated potential average crop calorie production of HII 30 is very close to the HIR caloric production, at $1.23 \times 10^{13} \mathrm{kcal}_{\text {year }}{ }^{-1}$, which is a potential increase of $778 \%$ compared to reference crop calorie production.

In LIR 50 the simulated average total crop calorie production is $7.4 \times 10^{12} \mathrm{kcal} \mathrm{year}^{-1}$ and it shows an increase of $428 \%$ compared to the reference crop calorie production. Similarly, in HIR 50 the result shows that the average total crop calorie production is $1.67 \times 10^{13} \mathrm{kcal}_{\text {year }}{ }^{-1}$ (as illustrated in Table 1). This is an increase of $1092 \%$ compared to the reference calorie crop production. In irrigated agriculture, average HII 50 crop calorie production is simulated to be $1.70 \times 10^{13} \mathrm{kcal}_{\text {year }}^{-1}$, which shows only about a $1.8 \%$ increase over the simulated HIR 50 crop calorie production. In general, the difference between rain-fed and irrigated agricultural crop calorie production is insignificant.

The reference crop calorie production could feed around 1.7 million people, assuming a daily diet of $2200 \mathrm{kcal} / \mathrm{cap} /$ day. Table 1 shows that the simulated potential LIR 30 and HIR 30 could feed around 6.6 and 15.0 million people, respectively. The same calculations reveal that within the LIR 50 low-intensity/large expansion scenario, Gambella's agriculture could supply the necessary calories for 9.2 million people. Improving agricultural technology, infrastructure, education and governance for the HIR 50 scenario would further increase to 21.0 million the number of people that can be fed by Gambella's agriculture. However, the introduction of irrigation in the HIR scenario only marginally increases this number, to around 21.3 million people. This indicates that the simulated potential of HIR 50 and HII 50 potential crop calorie production can feed about 19 times as many people as the reference crop calorie production. The results of the scenario simulations also make clear that the total potential production of calories in all scenarios far exceeds the current and possible future caloric demand of Gambella's population, thereby also freeing food resources for the national and international markets. 
Table 1. Crop (Mt year ${ }^{-1}$ ) and calorie $\left(\mathrm{kcal}_{\mathrm{year}}{ }^{-1}\right.$ ) production and number of people that can be nourished in the land use scenarios, with absolute number and relative percentage difference with reference to the reference yield/production.

\begin{tabular}{|c|c|c|c|c|}
\hline \multicolumn{2}{|c|}{ TOP $30 \%$ Area Scenario } & LIR 30 & HIR 30 & HII 30 \\
\hline \multirow{2}{*}{ Crop production } & Maize & $\begin{array}{c}1.8 \\
+350 \%\end{array}$ & $\begin{array}{c}4.4 \\
+1000 \%\end{array}$ & $\begin{array}{c}4.5 \\
+102 \%\end{array}$ \\
\hline & Sorghum & $\begin{array}{c}1.2 \\
+300 \%\end{array}$ & $\begin{array}{c}2.4 \\
+700 \%\end{array}$ & $\begin{array}{c}2.5 \\
+733 \%\end{array}$ \\
\hline \multicolumn{2}{|c|}{ Crop Calorie production } & $\begin{array}{c}5.4 \times 10^{12} \\
+286 \%\end{array}$ & $\begin{array}{c}1.20 \times 10^{13} \\
+757 \%\end{array}$ & $\begin{array}{c}1.23 \times 10^{13} \\
+778 \%\end{array}$ \\
\hline \multicolumn{2}{|c|}{ Number of people nourished (million) } & $\begin{array}{c}6.6 \\
+288 \%\end{array}$ & $\begin{array}{c}15 \\
+782 \% \\
\end{array}$ & $\begin{array}{c}15.5 \\
+812 \%\end{array}$ \\
\hline \multicolumn{2}{|c|}{ TOP $50 \%$ Area Scenario } & LIR 50 & HIR 50 & HII 50 \\
\hline \multirow{2}{*}{ Crop production } & Maize & $\begin{array}{c}2.5 \\
+525 \% \\
\end{array}$ & $\begin{array}{c}6.1 \\
+1425 \%\end{array}$ & $\begin{array}{c}6.3 \\
+1475 \%\end{array}$ \\
\hline & Sorghum & $\begin{array}{c}1.7 \\
+467 \%\end{array}$ & $\begin{array}{c}3.4 \\
+1033 \%\end{array}$ & $\begin{array}{c}3.5 \\
+1067 \%\end{array}$ \\
\hline \multicolumn{2}{|c|}{ Crop Calorie production } & $\begin{array}{c}7.4 \times 10^{12} \\
+428 \%\end{array}$ & $\begin{array}{c}1.67 \times 10^{13} \\
+1092 \%\end{array}$ & $\begin{array}{c}1.70 \times 10^{13} \\
+1114 \%\end{array}$ \\
\hline \multicolumn{2}{|c|}{ Number of people nourished (million) } & $\begin{array}{c}9.2 \\
+441 \%\end{array}$ & $\begin{array}{c}21.0 \\
+1135 \%\end{array}$ & $\begin{array}{c}21.3 \\
+1153 \%\end{array}$ \\
\hline
\end{tabular}

\section{Discussion}

In Gambella, agricultural intensification and cropland expansion are the two major policies/strategies to raise crop yields in particular and agricultural output in general [3]. Agricultural intensification by raising agricultural inputs to increase per-hectare yields has become central to policy formulation, primarily as a strategy for reducing agriculture encroachment into forests, protected areas and wetland areas. On the other hand, in Gambella cropland expansion is occurring due to rising food demand and population growth. According to UN reports, Ethiopia's population is expected to increase dramatically in the next 20-25 years [1,2], with the increase in food production falling behind population increase. Thus, we are arguing here that Gambella can serve as a backup for the country's potential food production.

Gambella region has huge potential for agricultural production (intensification) and an abundance of unutilized land (expansion) and has sufficient rainfall [38]. Our findings show that within Gambella's suitable cropland, the quantum of calories that can potentially be produced in HIR 50 agriculture can nourish $18 \%$ of today's total population of Ethiopia or $10 \%$ of the total population of Ethiopia in 2050. Thus, Gambella could potentially serve as a bread basket to enable food security for the country. Currently, the population of the region is around 436,000 , which is about $0.5 \%$ of the total population of Ethiopia. Our results indicate that the population of the study area can be self-sufficient even with the very conservative assumptions underlying the LIR 30 scenario and that the production can even increase by better organizing and managing the region's farming practices. In recent decades, several agricultural development activities have been carried out in the region to achieve sustainable production. In the 1990s, there were no trained agricultural development workers. However, since the beginning of the current century a total of 1700 youths have been trained as agricultural extension workers. Currently, these agricultural extension workers are active in the region's agriculture offices, assisting and teaching how subsistence farmers can minimize the yield gaps [62]. The major objective of these agriculture extension workers is also to focus on training local farmers to be efficient in planting and harvesting and to adopt modern agricultural systems and technologies [62,63]. Yet, the average yield gap between the small-scale farmers' production and the simulated potential yield is quite large. 
A lack of knowledge, poor agriculture technology and lack of modern inputs and innovations are the main contributory factors for low yield production per hectare in the region [38,64,65].

Our findings for potential yields are in agreement with other studies at country level or global scale. According to international food policy research institute (IFPRI) the potential production of average maize yield is around $4.7 \mathrm{t} \mathrm{ha}^{-1}$ on-farm field trials at country level, when cultivated with fertilizer, hybrid seed and farm management practices [66]. A local case study in Central Rift Valley region of Ethiopia shows similar results to our study. While we estimated an average water-limited potential yield for maize of $6.1 \mathrm{tha}^{-1}$, the average maize water-limited potential yield was $6.0 \mathrm{tha}^{-1}$ for the 2015/2016 seasons [21]. For sorghum, Kinfe and Tesfaye [67] found an average potential yield of $3.9 \mathrm{tha}^{-1}$ in the moist lowlands of the country. The global GAEZ model approach at 5 arc minutes spatial resolution estimated the average maize and sorghum potentials to be $10.6 \mathrm{tha}^{-1}$ and $6 \mathrm{tha}^{-1}$ respectively for the Gambella region [68].

The study confirmed that irrigation does not contribute to higher potential yield levels in the Gambella region, because it turned out from the PROMET simulations that water was not the main constraint for maize and sorghum growth. It is also clear that the favourable natural conditions for agriculture in the region could help to produce adequate food to match the population growth of the area. Our findings show that the spatial distribution of yield production in the region is higher in the northern and central part of the region but declines towards the south-eastern part of the region, due to the prevailing Alisols that consist of $51 \%$ sand, $27 \%$ silt and $22 \%$ clay. The sandy soils lead to high percolation due to low field capacities, which finally results in water stress and low yields $\left[1-3 \mathrm{tha} \mathrm{h}^{-1}\right]$. In addition, this soil contains few nutrients and has high accumulation of clays in the subsoil [69,70]. With the exception of this particular area, however, crops in most parts of the region do not experience water stress.

For further studies, it is also important to consider climate change impacts on potential yields for future projections. For the Gambella region, climate projections assume a $2.57 \%$ and $2.35 \%$ increase of precipitation for RCP 8.5 and for RCP 2.6 respectively and an increase of temperature by $1.73 \mathrm{~K}$ for RCP 8.5 and by $0.75 \mathrm{~K}$ for RCP 2.6 until 2050 (model mean of all CMIP5 models [71]). The small increase in precipitation may not necessarily result in higher yields, since (1) the increase in precipitation is assumed to take place from September to December, which is beyond the current growing period of maize and sorghum (2) increased temperature might result in less water availability due to increased evaporation rates.

On the other hand, TOP 30 and TO P50 cropland expansion has been identified as improving the potential food production in the region by 2050. However, the TOP 30 and TOP 50 cropland expansion for agriculture could threaten the native ecosystems [72]. In both scenarios, sufficient agricultural production to meet the human demand for food while maintaining the ecosystem functions and minimizing the environmental impacts is the greatest challenge [73,74] in the region. While we do not consider utilizing any legally protected land for expansion, our study also does not consider distributions of endemic richness and biodiversity. Since we have assumed the areas best suited for expansion, further investigations are necessary to determine whether these identified best expansion areas are important for biodiversity or other ecosystem service functions and consequently should be protected and preserved.

In Gambella, tropical grassland cover was 1,370,000 ha in 1987 and it has declined to around 911,200 ha in 2017 due to cropland expansion. If the cropland expansion continues at the same rate as is happening today, then around 504,680 ha tropical grasslands are expected to be converted into cropland by 2050 [39]. Meeting this challenge requires better understanding of the environmental impact of TOP 30 and TOP 50 cropland expansion in the region. Thus, when making policies it is important to focus on the role of cropping intensity related to food production, land use management and planning. Our findings also demonstrate that currently intensification may provide a promising opportunity to increase Gambella region's food production without the need for cropland expansion. In the past, because of cropland expansion widespread land and resource conversion has been occurring in many 
parts of the region, mainly due to large-scale farm investment and resettlement (internal migration) from other regions $[75,76]$.

To achieve the potential and sustainable food production in the future and to export significant food resources from the region to the national and international markets, the current status of agricultural production and estimated yields gaps, as well as the sustainability of the agricultural management and cropland expansion, need to be taken into account [77]. Based on this information, well-targeted land management decisions and potential food production can be achieved [48] in Gambella region.

\section{Conclusions}

This paper presents the Gambella region in Ethiopia as a case study for systematic exploration of the potential for agricultural intensification and cropland expansion to increase caloric production and food security. Realistic assumptions for intensification and cropland expansion were set and combined into 6 intensification/expansion scenarios which were analysed with respect to their food and caloric production potential. For this purpose, a spatially distributed hydro-ecological crop growth model identified the yield potentials of different management options as well as the feasible and most suitable regions for expansion of cropland. Overall, it can be stated that the framework that was set up to systematically develop and analyse the scenarios has proven its applicability for the selected test case. Since no assumptions which are specific to the test case enter the framework and since the selected model has already proven its global applicability, we assume that the framework is transferable to carry out similar studies in other regions of the globe.

The important practical results that can be drawn from the scenario analysis of the Gambella region are: (1) there is tremendous potential to increase rain-fed yields of maize and sorghum by increasing agricultural inputs through mechanization and fertilization and by improving infrastructure, education and governance; (2) there is similarly large potential for expanding cropland; the preferred areas for agricultural expansion in the region have been identified; (3) the rather low added potential of irrigation does not justify generally introducing it on a large scale; (4) Gambella's agricultural potential far exceeds its caloric demands and the region could theoretically go on without expansion, securing food supply for its current and future population and preserving natural resources like biodiversity, water resources and soil fertility for the demand of future generations; (5) the potential, if exploited, would allow export of significant food resources from Gambella to the national and international markets.

Supplementary Materials: The following are available online at http://www.mdpi.com/2077-0472/9/5/105/s1, Table S1: List of nutritive factors ( $\left.\mathrm{f}^{\mathrm{i}}\right)$ for crop products.

Author Contributions: Conceptualization, A.W.D., F.Z. and W.M.; methodology, A.W.D., F.Z. and W.M.; software, W.M.; validation, A.W.D.; formal analysis, A.W.D., F.Z. and W.M.; investigation, A.W.D.; resources, A.W.D.; data curation, A.W.D.; writing—original draft preparation, A.W.D.; writing—review and editing, A.W.D., F.Z. and W.M.; visualization, A.W.D.; supervision, F.Z. and W.M. All authors read and approved the final manuscript.

Acknowledgments: Our special gratitude goes to the Ethiopian Ministry of Agriculture (MOA) staff, National Agricultural Statistic Service office, Ethiopia's annual Agricultural Sample Survey (AgSS) office and Ethiopia's Central Statistics Authority (CSA) for their support during the field data collection in 2018. At last but not least, I wish to acknowledge the financial support of German Academic Exchange Service (DAAD) and for giving me the opportunity to pursue my doctoral degree in Germany.

Conflicts of Interest: The authors declare no conflicts of interest.

\section{References}

1. World Population Review. Ethiopia Population. Available online: https://www.worldpopulationreview.com/ countries/ethiopia-population/ (accessed on 13 January 2019).

2. Bekele, A.; Lakew, Y. Projecting Ethiopian Demographics from 2012-2050 Using the Spectrum Suite of Models; Ethiopian Public Health Association (EPHA): Addis Ababa, Ethiopia, 2014.

3. Mekuria, W. The link between agricultural production and population dynamics in Ethiopia: A review. Adv. Plants Agric. Res. 2018, 8, 348-353. [CrossRef] 
4. IFAD. HIGHLIGHTS ANNUAL REPORT 2012. Available online: https://www.ifad.org/documents/38714170/ 39625681/annual+report+2012+english+final+print.pdf/664e5cf9-8166-4d43-9db2-f5d4b6a9eb03 (accessed on 3 November 2019).

5. Demeke, M.; Guta, F.; Ferede, T.; ADDIS ABABA. Agricultural Development in Ethiopia: Are There Alternatives to Food Aid? Department of Economics, Addis Ababa University: Addis Ababa, Ethiopia, 2004. Available online: www.sarpn.org.za/documents/d0001583/FAO2005_Casestudies_Ethiopia.pdf (accessed on 12 February 2019).

6. Ayenew, M.M.; Kopainsky, B. Food insecurity in Ethiopia: Population, food production and market. In Proceedings of the 32nd International Conference of the System Dynamics Society, Delft, The Netherlands, 20-24 July 2014.

7. Endalew, B.; Muche, M.; Tadesse, S. Assessment of food security situation in Ethiopia: A Review. Asian J. Agric. Res. 2015, 9, 55-68. [CrossRef]

8. Kugbei, S.; Turner, M.; Witthaut, P. Finance and Management of Small-Scale Seed Enterprises; ICARDA: Beirut, Lebanon, 2000.

9. Se, A.S.T.; Dorosh, P.; Gemessa, S.A. Crop Production in Ethiopia: Regional Patterns and Trends; International Food Policy Research Institute: Addis Ababa, Ethiopia, 2011; p. 53.

10. Schneider, K.; Anderson, L. Yield gap and productivity potential in Ethiopian agriculture: Staple grains \& pulses. EPAR Brief 2010, 98. Available online: www.evans.uw.edu/policy-impact/epar/research/yield-gapand-productivity-potential-ethiopian-agriculture-staple-gains (accessed on 15 November 2018).

11. Von Grebmer, K.; Bernstein, J.; de Waal, A.; Prasai, N.; Yin, S.; Yohannes, Y. 2015 Global Hunger Index: Armed Conflict and the Challenge of Hunger; International Food Policy Research Institute: Washington, DC, USA, 2015.

12. Foley, J.A.; Ramankutty, N.; Brauman, K.A.; Cassidy, E.S.; Gerber, J.S.; Johnston, M.; Mueller, N.D.; O'Connell, C.; Ray, D.K.; West, P.C. Solutions for a cultivated planet. Nature 2011, 478, 337. [CrossRef]

13. Phalan, B.; Green, R.; Balmford, A. Closing yield gaps: Perils and possibilities for biodiversity conservation. Phil. Trans. R. Soc. B 2014, 369, 20120285. [CrossRef]

14. Byerlee, D.; Stevenson, J.; Villoria, N. Does intensification slow crop land expansion or encourage deforestation? Glob. Food Secur. 2014, 3, 92-98. [CrossRef]

15. Barbier, E.B. Explaining agricultural land expansion and deforestation in developing countries. Am. J. Agric. Econ. 2004, 86, 1347-1353. [CrossRef]

16. Tilman, D.; Balzer, C.; Hill, J.; Befort, B.L. Global food demand and the sustainable intensification of agriculture. Proc. Natl. Acad. Sci. USA 2011, 108, 20260-20264. [CrossRef] [PubMed]

17. Chamberlin, J.; Jayne, T.; Headey, D. Scarcity amidst abundance? Reassessing the potential for cropland expansion in Africa. Food Policy 2014, 48, 51-65. [CrossRef]

18. Tadesse, D. Gambella The Impact of Local Conflict on Regional Security; Institute for Security Studies: Addis Ababa, Ethiopia, 2007.

19. Cascão, A.E. Resource-Based Conflict in South Sudan and Gambella (Ethiopia): When Water, Land and Oil Mix with Politics; ISCTE: Lisbon, Portugal, 2013.

20. Hillocks, R. Addressing the yield gap in Sub-Saharan Africa. Outlook Agric. 2014, 43, 85-90. [CrossRef]

21. Admassie, A.; Assefa, B.; Descheemaeker, K. Reducing the Maize Yield Gap in Ethiopia: Analysis and Policy Simulation; Ethiopian Economics Association: Addis Ababa, Ethiopia, 2017.

22. Alemu, G.T.; Berhanie Ayele, Z.; Abelieneh Berhanu, A. Effects of Land Fragmentation on Productivity in Northwestern Ethiopia. Adv. Agric. 2017, 2017, 1-9. [CrossRef]

23. Sewnet, Y.; Elemo, E.; Derso, D. A review of agricultural research, extension and farmers linkage in Ethiopia. Agric. Biol. J. Am. 2016, 7, 116-120.

24. Gálvez-Nogales, E.; Fonseca, J. Institutional Procurement of Staples from Smallholders: The Case of Purchase for Progress in Ethiopia; FAO: Rome, Italy, 2014.

25. Lobell, D.B.; Cassman, K.G.; Field, C.B. Crop yield gaps: Their importance, magnitudes, and causes. Annu. Rev. Environ. Resour. 2009, 34, 179-204. [CrossRef]

26. Mueller, N.D.; Gerber, J.S.; Johnston, M.; Ray, D.K.; Ramankutty, N.; Foley, J.A. Closing yield gaps through nutrient and water management. Nature 2012, 490, 254-257. [CrossRef] [PubMed]

27. Mauser, W.; Klepper, G.; Zabel, F.; Delzeit, R.; Hank, T.; Putzenlechner, B.; Calzadilla, A. Global biomass production potentials exceed expected future demand without the need for cropland expansion. Nat. Commun. 2015, 6, 8946. [CrossRef] [PubMed] 
28. Müller, C.; Elliott, J.; Chryssanthacopoulos, J.; Arneth, A.; Balkovic, J.; Ciais, P.; Deryng, D.; Folberth, C.; Glotter, M.; Hoek, S. Global gridded crop model evaluation: Benchmarking, skills, deficiencies and implications. Geosci. Model Dev. Discuss. 2017, 10, 1403-1422. [CrossRef]

29. Woube, M. Flooding and sustainable land-water management in the lower Baro-Akobo river basin, Ethiopia. Appl. Geogr. 1999, 19, 235-251. [CrossRef]

30. Gebresenbet, F. Land acquisitions, the politics of dispossession, and state-remaking in Gambella, Western Ethiopia. Afr. Spectr. 2016, 51, 5-28. [CrossRef]

31. Wakuma Abaya, S.; Mandere, N.; Ewald, G. Floods and health in Gambella region, Ethiopia: A qualitative assessment of the strengths and weaknesses of coping mechanisms. Glob. Health Action 2009, 2, 2019. [CrossRef]

32. Dika, G. Impacts of Climate Variability and Households Adaptation Strategies in Lare District of Gambella Region, South Western Ethiopia. J. Earth Sci. Clim. Chang. 2018, 9, 2. [CrossRef]

33. Sewonet, A. Breaking the Cycle of Conflict in Gambella Region; UN-Emergencies Unit for Ethiopia: Addis Ababa, Ethiopia, 2002.

34. Awulachew, S.B.; Yilma, A.D.; Loulseged, M.; Loiskandl, W.; Ayana, M.; Alamirew, T. Water Resources and Irrigation Development in Ethiopia; IWMI: Colombo, Sri Lanka, 2007; ISBN 978-92-9090-680-3.

35. Central Statistical Agency. Population Projection of Ethiopia for All Regions At Wereda Level from 2014-2017; Central Statistical Agency: Addis Ababa, Ethiopia, 2018.

36. Olay, K.O.; Okumo, O.O. The Effect of Large Agricultural Investment Projects on the Local People in Ethiopia "The Case of Gambella Region". Imp. J. Interdiscip. Res. 2017, 3, 732-740.

37. Degife, A.W.; Mauser, W. Socio-economic and Environmental Impacts of Large-Scale Agricultural Investment in Gambella Region, Ethiopia. J. US-China Public Adm. 2017, 14, 183-197.

38. Yassin, A. Transnational Large Scale Agricultural Firms in Gambella Regional State, Ethiopia: Local Potentials, Opportunities and Constraints for Market Linkage and Contractual Farming Schemes; Future Agricultures Consortium: Brighton, UK, 2014.

39. Degife, A.W.; Zabel, F.; Mauser, W. Assessing land use and land cover changes and agricultural farmland expansions in Gambella Region, Ethiopia, using Landsat 5 and Sentinel 2a multispectral data. Heliyon 2018, 4, e00919. [CrossRef]

40. Snow, K.H. Livelihoods E Vulnerabilities Study Gambella Region of Ethiopia; UNICEF: Addis Ababa, Ethiopia, 2006; p. 13.

41. Lemessa, D.; Officer, U.-E.A.F. Food Shortages and Seasonal Floods: Major Recurrent Threats to Gambella Region; Undp Emergencies Unit Ethiopia: Addis Ababa, Ethiopia, 1999.

42. Dorosh, P.; Rashid, S. Food and Agriculture in Ethiopia: Progress and Policy Challenges; University of Pennsylvania Press: Philadelphia, PA, USA, 2013.

43. Mann, M.; Warner, J. Ethiopian Wheat Yield and Yield Gap Estimation: A Small Area Integrated Data Approach; International Food Policy Research Institute: Washington, DC, USA, 2015.

44. Woo, J. Rainfall Variability and Crop Yield Potential; International Food Policy Research Institute: Washington, DC, USA, 2010.

45. Mauser, W.; Bach, H.; Frank, T.; Hank, T.; Koch, F.; Marke, T.; Muerth, M.; Prasch, M.; Strasser, U.; Zabel, F. PROMET-Processes of Mass and Energy Transfer. An Integrated Land Surface Processes and Human Impacts Simulator for the Quantitative Exploration of Human-Environment Relations. Available online: http://www. geographie.unimuenchen.de/department/fiona/forschung/projekte/promet_handbook/index.html (accessed on 16 November 2018).

46. Zabel, F.; Mauser, W. 2-way coupling the hydrological land surface model PROMET with the regional climate model MM5. Hydrol. Earth Syst. Sci. 2013, 17, 1705-1714. [CrossRef]

47. Hank, T.B.; Bach, H.; Mauser, W. Using a remote sensing-supported hydro-agroecological model for field-scale simulation of heterogeneous crop growth and yield: Application for wheat in central Europe. Remote Sens. 2015, 7, 3934-3965. [CrossRef]

48. Bach, H.; Klug, P.; Ruf, T.; Migdall, S.; Schlenz, F.; Hank, T.; Mauser, W. Satellite image simulations for model-supervised, dynamic retrieval of crop type and land use intensity. In Proceedings of the 36th International Symposium on Remote Sensing of Environment, Berlin, Germany, 11-15 May 2015; pp. 1-7.

49. Fantaye, K.T. Application of the GYGA Approach to Ethiopia; Global Yield Gap Atlas: Addis Ababa, Ethiopia, 2016. 
50. Van Ittersum, M.K.; Cassman, K.G.; Grassini, P.; Wolf, J.; Tittonell, P.; Hochman, Z. Yield gap analysis with local to global relevance-A review. Field Crop. Res. 2013, 143, 4-17. [CrossRef]

51. Dee, D.P.; Uppala, S.M.; Simmons, A.; Berrisford, P.; Poli, P.; Kobayashi, S.; Andrae, U.; Balmaseda, M.; Balsamo, G.; Bauer, D.P. The ERA-Interim reanalysis: Configuration and performance of the data assimilation system. Q. J. R. Meteorol. Soc. 2011, 137, 553-597. [CrossRef]

52. Dudley, N.; Stolton, S. Defining protected areas: An international conference in Almeria, Spain. Iucngland 2008, 21-26.

53. EPRDF. A proclamation to provide for the conservation. Development and utilization of forests. In Negarit Gazeta; Proclamation NO. 94/1994; Ministry of Natural Resources Development and Environmental Protection, Ed.; Berhanena Selam Printing: Addis Ababa, Ethiopia, 1994.

54. Amsalu, T.; Addisu, S. A review of Wetland Conservation and Management Policy in Ethiopian. Int. J. Sci. Res. Publ. 2014, 4, 656-662.

55. Ray, D.K.; Mueller, N.D.; West, P.C.; Foley, J.A. Yield trends are insufficient to double global crop production by 2050. PLoS ONE 2013, 8, e66428. [CrossRef]

56. Central Statistical Agency. Agricultural Sample Survey Area and Production of Major Crops; Ministry of Agriculture Ethiopia: Addis Ababa, Ethiopia, 2017.

57. Central Statistical Agency. Agricultural Sample Survey Area and Production of Major Crops (Private Peasant Holdings, Meher Season); Central Statistical Agency (CSA): Addis Ababa, Ethiopia, 2017; pp. 1-112.

58. FAO. A Handbook Food Balance Sheets; FAO: Rome, Italy, 2001.

59. Pradhan, P.; Lüdeke, M.K.; Reusser, D.E.; Kropp, J.P. Embodied crop calories in animal products. Environ. Res. Lett. 2013, 8, 044044. [CrossRef]

60. Davis, K.F.; Seveso, A.; Rulli, M.C.; D'Odorico, P. Water savings of crop redistribution in the United States. Water 2017, 9, 83. [CrossRef]

61. United Nations Department of Economic and Social Affairs. World Population Prospects, United Nations Department of Economic and Social Affairs; Population Division: New York, NY, USA, 2017.

62. Abdusemed, A. Ethiopia: Gambella Is Thriving in Agricultural Productivity. The Ethiopian Herald, 30 December 2015.

63. Dula, T. Review on the Contribution of Agricultural Extension on Increasing Smallholder Farm Productivity in Case of Ethiopia. J. Cult. Soc. Dev. 2018, 40, 42-49.

64. Kagima, D.K. Training Programs in Sustainable Agriculture for Postharvest Loss Minimization and Storage: A Case Sudy in Ethiopia; Iowa State University: Ames, IA, USA, 2005.

65. Abate, T.; Shiferaw, B.; Menkir, A.; Wegary, D.; Kebede, Y.; Tesfaye, K.; Kassie, M.; Bogale, G.; Tadesse, B.; Keno, T. Factors that transformed maize productivity in Ethiopia. Food Secur. 2015, 7, 965-981. [CrossRef]

66. Rashid, S.; Getnet, K.; Lemma, S. Maize value chain potential in Ethiopia: Constraints and opportunities for enhancing the system. F1000Research 2019, 3, 2-40.

67. Kinfe, H.; Tesfaye, A. Yield performance and adoption of released Sorghum varieties in Ethiopia. Edelweiss Appl. Sci. Technol. 2018, 2, 46-55. [CrossRef]

68. Fischer, G.; Nachtergaele, F.O.; Prieler, S.; Teixeira, E.; Tóth, G.; van Velthuizen, H.; Verelst, L.; Wiberg, D. Global Agro-Ecological Zones (GAEZ v3. 0)-Model Documentation; IIASA: Laxenburg, Austria; FAO: Rome, Italy, 2012.

69. Batjes, N.H. Harmonized soil profile data for applications at global and continental scales: Updates to the WISE database. Soil Use Manag. 2009, 25, 124-127. [CrossRef]

70. Lakew, A.M.; Moog, O. Top-down Operative Stream Classification System (typology) for Ethiopian Highlands; Austrian Partnership Programme in Higher Education \& Research for Development: Larima, Vienna, Austria, 2016; p. 23.

71. Taylor, K.E.; Stouffer, R.J.; Meehl, G.A. An Overview of CMIP5 and the Experiment Design. Bull. Am. Meteorol. Soc. 2012, 93, 485-498. [CrossRef]

72. Perrings, C.; Halkos, G. Agriculture and the threat to biodiversity in sub-saharan Africa. Environ. Res. Lett. 2015, 10, 095015. [CrossRef]

73. Godfray, H.C.J.; Garnett, T. Food security and sustainable intensification. Philos. Trans. R. Soc. B Biol. Sci. 2014, 369, 20120273. [CrossRef] 
74. Molotoks, A.; Stehfest, E.; Doelman, J.; Albanito, F.; Fitton, N.; Dawson, T.P.; Smith, P. Global projections of future cropland expansion to 2050 and direct impacts on biodiversity and carbon storage. Glob. Chang. Biol. 2018, 24, 5895-5908. [CrossRef]

75. Teshome, M. Population growth and cultivated land in Rural Ethiopia: Land use dynamics, access, farm size, and fragmentation. Resour. Environ. 2014, 4, 148-161.

76. Devereux, S.; Sussex, I. Food Insecurity in Ethiopia; Institute for Development Studies: Brighton, UK, 2000.

77. Jones, J.W.; Antle, J.M.; Basso, B.; Boote, K.J.; Conant, R.T.; Foster, I.; Godfray, H.C.J.; Herrero, M.; Howitt, R.E.; Janssen, S. Toward a new generation of agricultural system data, models, and knowledge products: State of agricultural systems science. Agric. Syst. 2017, 155, 269-288. [CrossRef]

(C) 2019 by the authors. Licensee MDPI, Basel, Switzerland. This article is an open access article distributed under the terms and conditions of the Creative Commons Attribution (CC BY) license (http://creativecommons.org/licenses/by/4.0/). 